\title{
ADAPTATION PROBLEMS OF THE POST INDUSTRIAL HERITAGE ON THE EXAMPLE OF SELECTED OBJECTS OF BYDGOSZCZ
}

\author{
Michał PSZCZÓŁKOWSKI ${ }^{1}$ \\ Academy of Fine Arts in Gdansk, Gdańsk, Poland
}

\begin{abstract}
Post-industrial architecture was until recently regarded as devoid of value and importance due to obsolescence, but this awareness has been a clear change in recent years. The old factories become full-fledged cultural heritage, as evidenced by the inclusion of buildings and complexes of this type in the register of monuments and protected by their conservator. More and more often, therefore, one undertakes revitalization of degraded brownfield sites, and within these treatments - conversion works. Specific issues and problems related to the adaptation of industrial facilities are discussed in the article on the basis of selected examples, completed in recent years in Bydgoszcz.
\end{abstract}

Keywords: post-industrial heritage, adaptation, revitalization, Bydgoszcz

\section{INTRODUCTION}

Architecture and industrial building from the time of industrial development is an integral part of large cities. In the post-war years industrial buildings were mostly used for its original purpose, whereas after 1989 the situation changed due to the process of industrial restructuring. The spatial effects of these transformations are visible in the form of so-called post-industrial wasteland, i. e. the grounds and buildings abandoned and undergoing progressive

\footnotetext{
${ }^{1}$ Corresponding author: Academy of Fine Arts in Gdansk, Inter-Faculty Department of the Sciences of Art, 6 Targ Węglowy, 80-836 Gdańsk, Poland, e-mail: michal.pszczolkowski@asp.gda.pl, tel. 511479164
} 
degradation. Until recently, due to the overuse of technology, they have been regarded as devoid of value and meaning, however, this awareness has been a marked change in recent years. It is becoming increasingly common to appreciate the cultural values of this branch of architecture, also in terms of history and aesthetics. Industrial architecture becomes - gradually - a fullfledged cultural heritage, as evidenced by the integration of further buildings and complexes of this type in the register of monuments and protected by their conservator.

The increasingly common phenomenon in recent years has become degraded brownfield revitalization. As part of these operations one makes the conversion works, converting former factories into modern hotels, lofts, objects related to trade and the broadly defined culture. Interesting examples of such works are known from Łódz [11], Poznań [6], Białystok [2], Gliwice [7], Żyrardów [4] and many other cities. This phenomenon should be evaluated fully positively, thanks to it for abandoned objects are restored to life. However, such investments are a big challenge for designers, as a rule, who are obliged to adapt to the existing architectural substance and to preserve its aesthetic. Meanwhile, the adaptation of industrial facilities, and so the adaptation of the object designed to perform a specific function to the new, more or less different utility tasks, must be related to the redevelopment of premises, interference with elevations or functional transformation of the facility and its immediate surroundings. So how to meet the requirements of the investor and to satisfy economic considerations, while properly solve the issue from conservation point of view?

After 2000, a number conversion works were performed in Bydgoszcz - the city which has a particularly rich post-industrial heritage, related to economic development at the turn of the XIX and XX century. Some of the buildings constructed to this day serve as the production function; the others are adapted to more or less distinct needs. A review of these works will identify specific problems related to the adaptation of post-industrial facilities, and the possibility of solving them.

\section{THE EXAMPLES OF CONVERSION}

\subsection{Kentzer's Mill - Hotel "Sunny Mill"}

In 2007-2009, there was a revitalization of so-called Kentzer's Mills, of the second half of the nineteenth century, degraded even in times of communism. Buildings of old mill and a grain warehouse has been adapted for Hotel "Sunny 
Mill" according to the design of Futura studio directed by Andrzej Malingowski.
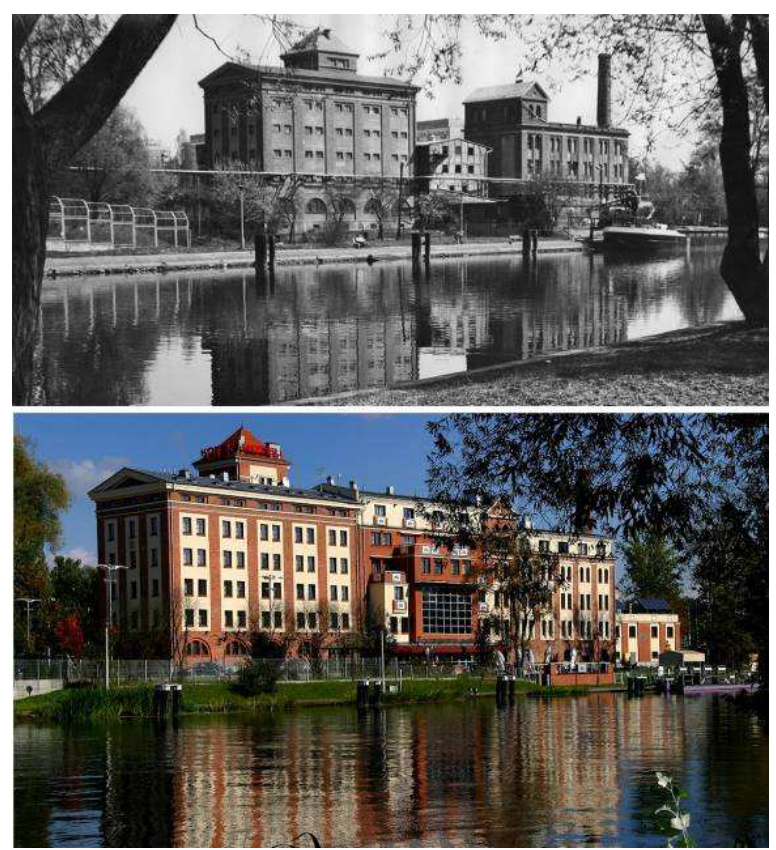

Fig. 1. Kentzer's mills - the state before adaptation, design and the status after adaptation

For the purposes of the hotel one dedicated three main mill buildings and warehouse. Due to the very bad technical condition one decided to liquidate the half-timbered wall structure granary between mills buildings, in its place was built a connector (main hall, reception and restaurant) of modern architecture, properly associated with existing objects. The challenge for the designer was, among others, to accommodate the different levels in different buildings. The problem was solved by designing inside the connector two elevator shafts, while giving up the stairs - instead of them one built ramps, allowing the use of the facility by people with disabilities [3]. Kentzer's Mills adaptation was showered with awards, including the main prize of Friends Society of Bydgoszcz "Phoenix 2009" and the first prize in the competition "The Golden Ribbon of Brda 2010" in the category of service facilities, but that does not exclude defects and shortcomings. Serious doubts are raised by exclusive interior design (including the 11-meter chandelier made of artificial crystal), perhaps desirable in a four-star hotel, but receding original character. Does the hotel in the former mill necessarily have to look like any other hotel? Architect originally intended to use some of the details of the demolition of the granary, among others, wooden shoe to slide bags of flour. Unfortunately, in the heat of 
works and constantly changing construction crews these elements ... were lost. Such situations are totally unacceptable, original architectural elements should be, in fact, stored in a specifically designed and properly secured place.

\subsection{Mill Island}

Another example of industrial heritage care is a comprehensive revitalization of Mill Island. Mill Island, surrounded by the waters of the Brda and Młynówka, is located in the very centre of Bydgoszcz, a few dozen meters from the Old Market Square. Its name comes from the numerous mills, localized here since medieval times (most modern buildings dating from the eighteenth and nineteenth century). Industrial function of this area ended in the $70 \mathrm{~s}$ of the twentieth century; four of the ten preserved historic buildings were handed over for use to the Regional Museum, yet the surroundings has started to undergo gradual degradation and destruction. At the beginning of the twenty-first century, space of the Island was devastated, overgrown and badly lit, buildings were absorbed by moisture, and in the evening it was better not to venture here. In 2004, Bydgoszcz authorities prepared a program of revitalization of cultural and natural resources of Mill Island and its immediate surroundings, deciding to transform the area in the space of culture, recreation and tourism. In the years 2006-2012 there were extensive revitalization works by Warsaw studio project "Grupa 3J" and the team of designers under the direction of Rafał Sotkowski. The most important element of the project was the renovation and adaptation of five historic buildings of the District Museum and one for the Centre for Work and Entrepreneurship. The work also covered the environment: additional footbridges were built, connecting the island with the town, paths and cycle paths, a playground, an amphitheatre and elements of the "small architecture", one carried out renovation and reconstruction of historical street of so-called Międzywodzie and one made development of green areas, creating the so-called recreation meadow. One implemented new lighting and one strengthened quay. The final stage of work was the construction of the so-called marina - a modern haven with tourist accommodation, restaurant and technical infrastructure by the project of Warsaw studio ZIVVA (Tomasz Rokicki and Katarzyna Wojciechowska). In this way, the Mill Island has become a real gem and landmark of the city, a place of walks and recreation for residents and numerous cultural events [10].

Issues related to the implementation of the project were, among others, associated with catastrophic technical condition of two historic buildings, i. e. the former home of mill workers and so-called Miller House (including uneven settlement of foundations, extensive cracking, moisture and mildew). In this situation, it was decided to demolish two buildings to the basement level, and 
then - after completing new foundation piles - to restore it to its original form, using building materials from demolition. A wider range of intervention also required so-called Red Granary from 1861, dominant architectural buildings from the Old Market. The building was allocated to the Gallery of Modern Art, a large granary floor surfaces allowed for the organization of the exhibition halls without significant transformations of the original functional system. As work progressed, however, it was found bulging longitudinal walls of the building and deflect from the vertical, therefore it was necessary to toughen it spatially, it was realized in the form of steel trusses, placed in the space of the ground floor and the first and second floors. In addition, the existing vertical communication in the form of ladder stairs, typical of the granary buildings, did not allowed to use the building as a public facility. Accordingly, one planned new communication route in the form of an external staircase. It was designed using modern, steel-and-glass structure, which allowed it to be identified as the added element.

\subsection{DAG Fabrik - Exploseum}

Intensive actions on adaptation of Bydgoszcz industrial heritage were carried out in recent years on the vast premises of the former explosives factory Dynamit AG in the years 1939-1945. In the post-war years most of the factory buildings were taken over for the purposes of Chemical Plant "Zachem", some production zones were not effectively used since the war ended, slipping into a state of devastation. At the beginning of this century the local environment lovers of monuments became interested in the production area of nitroglycerine, composed of two twin production lines (each line consisted of eight individually designed buildings for the subsequent stages of production). In 2007, the city authorities submitted NGL zone into the competence of the Regional Museum of recommendation of organising museum and tourist functions. Financing of the project was made possible by taking into account investment in the Regional Operational Programme 2007-2013.

Adaptation embraced one of the two production lines: Exploseum was founded there - the centre of military techniques DAG Fabrik Bromberg. The architectural design based on the general concept of Michał Pszczółkowski was made in Gdynia studio Kleczkowski Architect. Due to the unique nature of the unit, associated with historical values, architectural-constructional and landscape, in designing adaptations one adopted the principle of maximum respect for the original and reduced the scale of intervention for necessary action. 

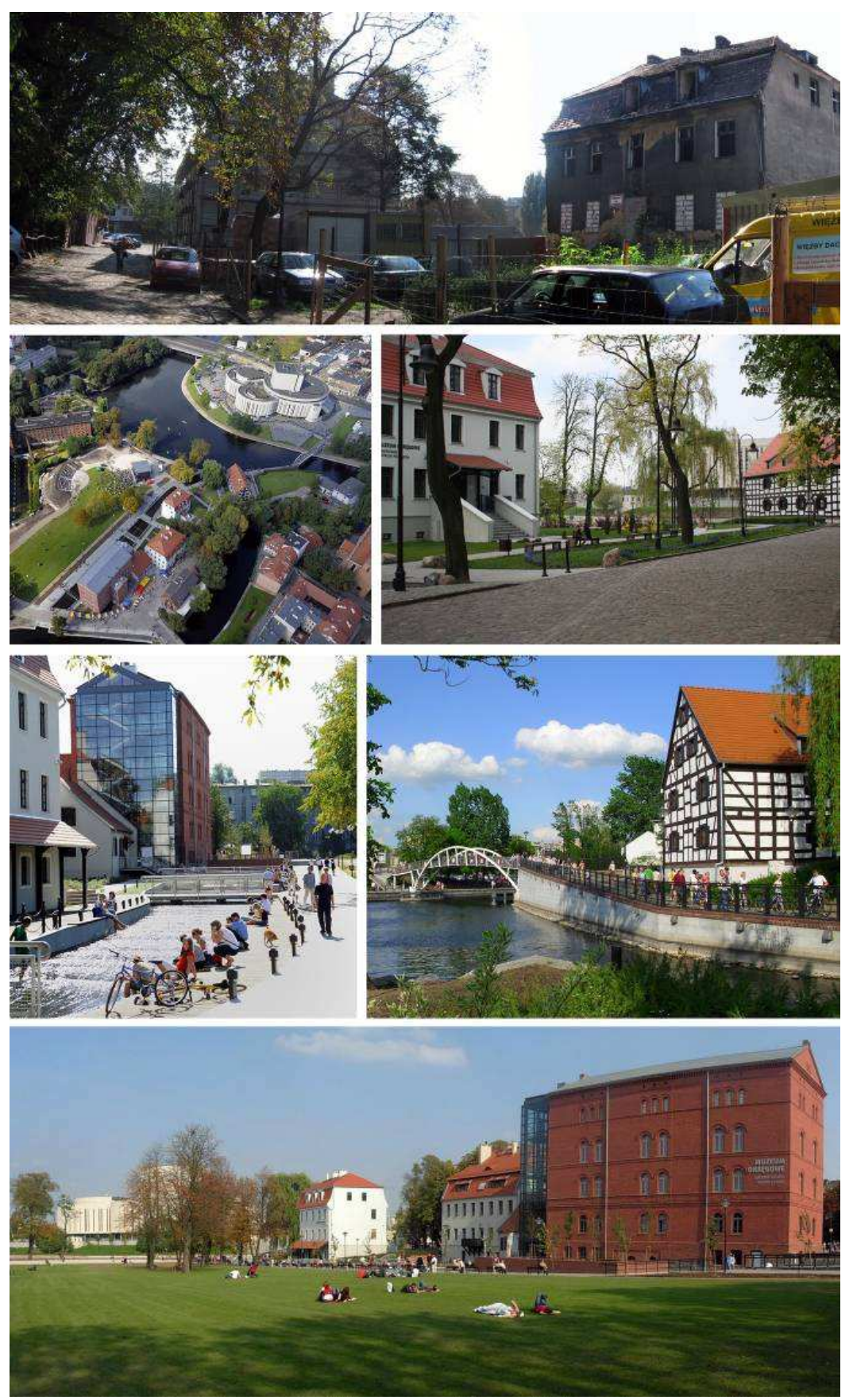

Fig. 2. The Mills Island - state before and after adaptation 

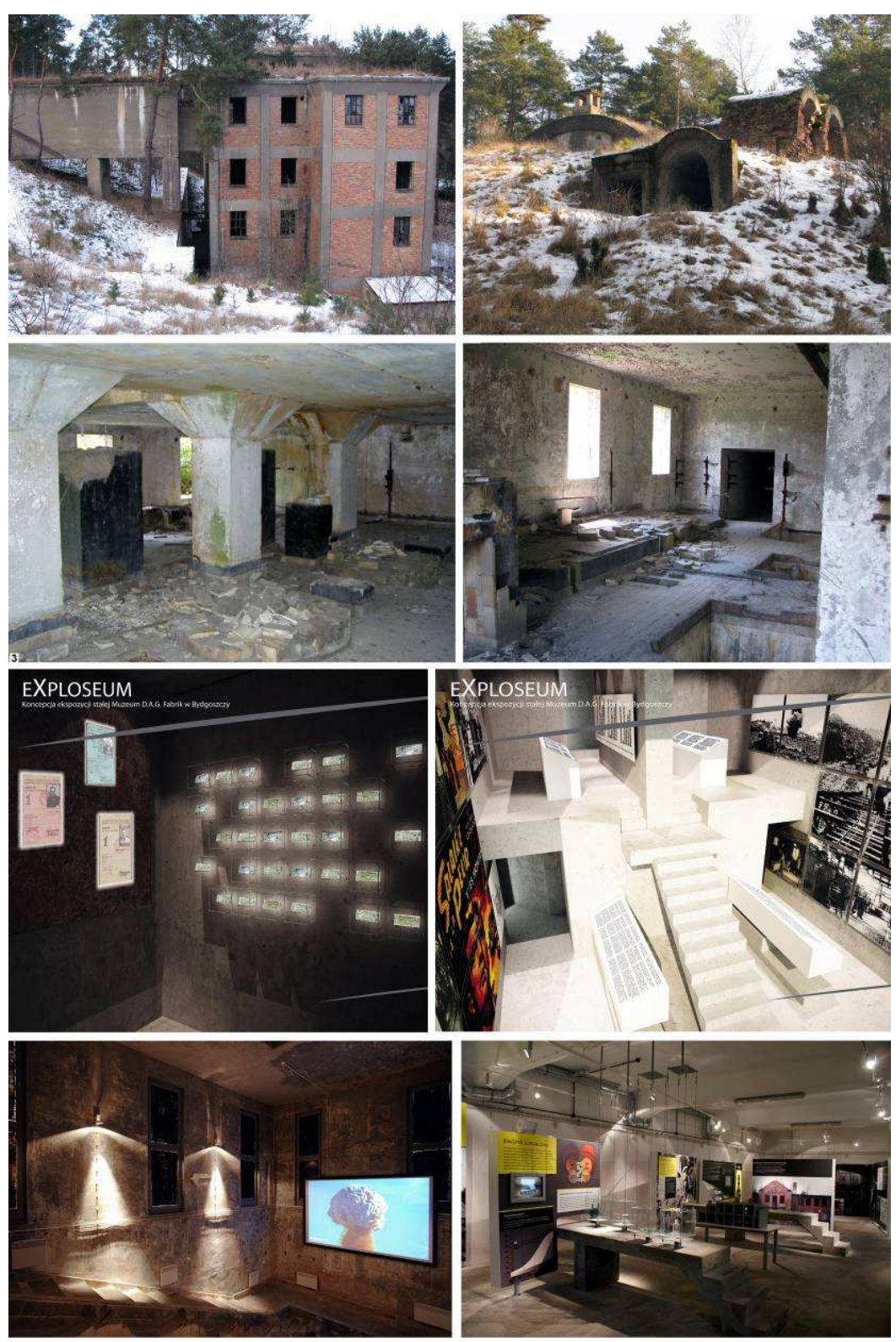

Fig. 3. NGL zone - the state before adaptation, interior design and state after the adaptation

The buildings were subjected to strict conservation treatments, limited to cleaning the facade and interior walls and strengthening structural elements. Installations were only performed superficially, which left the preservation of 
masonry structures intact and made it easier to access in case of any accident, and at the same time it stressed the industrial character of the interior.

The necessary supplements and new elements, both indoors (installations, carpentry windows, lamps in buildings and tunnels, cranes) and outdoors (benches, external staircase) were designed in the industrial convention, operating with concrete and steel and the simple, utilitarian forms.

\section{CONCLUSIONS}

Object adaptation to the new function should be primarily a way to protect its cultural values, hence, the new function should be selected in such a way as to be able to maintain and even enhance the value, determined individually for each object. In one case the dominant will be the scientific value (historical), in the second architectural or landscape; Of course there are also larger objects devoid of value. The new feature will be adjusted correctly if the conversion works are carried out in accordance with the conservation principle of minimum necessary intervention, being hand in hand with economic benefit of the investor. It should be taken as the principle that the greater will be the scope of adaptation and modernization, the greater depreciation of historic values. Necessary modernization works should be carried out with the use of safe, reversible technologies. It is about solutions such as e. g. distanced drywalls instead of plaster, under the panels and hidden installations, plastic shower cubes instead of the classic bathrooms, tiles mounted on the mounting grids, rather than stuck on the wall, etc. This rule stems not only from theoretical considerations of monuments protection, but also has practical and economical rationale [12]. Organization of construction site must safeguard original features and details; in a mess of construction works, they will be exposed to destruction, one must, therefore, provide the right solutions at the design stage and do not use makeshift solutions.

Due to the desired function of teaching it is also essential for the proposed function be public and widely available. The case of teaching function requires the development, for it seems that - especially in the case of adaptation for commercial purposes - historical and cultural value of industrial architecture are neglected. For example, a client of Focus Park in Bydgoszcz today mostly has no idea that they are located on the site of the former municipal slaughterhouse, and guest of "Sunny Mill" only the name may lead to earlier assumptions about the former function of the building, where they sleep. Sometimes even that perfect modernization completely blurs the original architectural character, so that sometimes one can have the impression that one deals with a completely new investment. Value in use is important, but in the hierarchy of architectural 
values higher values are the values of cultural, aesthetic and ethical [1]. Therefore, it is important in adaptation projects to include the clear signs of previous function. It is desirable to leave a "museum" fragment, talking about the kind of old production, for example, barrels at the brewery or looms in the spinning mill [8]. It may also be, for example, a mini-exhibition of multimedia, located in the lobby or other communal space, it can be kind of the educational path in the form of, distributed on-site, information about the original purpose of each room, supplemented by archival photographs or original elements of technical equipment or a sound guide as a sort of "time machine"; possibilities for creative designer here are very large. This allows customers of a shopping mall or restaurant guests while shopping or dining to learn something about the place where they are, not only in terms of manufacturing or construction issues. Even in Bydgoszcz hardly anyone knows that, for example, in the municipal slaughterhouse in 1937 a notorious American writer Jerome Salinger, author of "The Catcher in the Rye", had several months of practice (writer's letters have survived from this period, written to Ernest Hemingway) [5]. Such unconventional elements may be used for advertising and certainly attract customers. Above all, former factories, animated again, will be able not only to play the role of economic, but also serve an educational function and promote the development of increasingly popular industrial tourism.

\section{REFERENCES}

1. Basista A.: Architektura i wartości, Kraków, Universitas 2009.

2. Dąbrowska-Milewska G.: Nowe życie dawnej architektury przemystowej. Przyktady z „Manchesteru Pótnocy”, „Czasopismo Techniczne. Architektura", 108, 4-A/1 (2011), 92-96.

3. Gregorczyk A.: Sztuka harmonijnego dopasowania. Rewitalizacja bydgoskich Młynów Kentzera, „Zawód Architekt”, 5, 5 (2011), 74-81.

4. Komża J.: Żyrardów. Rewitalizacja dziedzictwa i odbudowa tożsamości miasta, w: Rewitalizacja dziedzictwa przemystowego, redaktor J. Kołodziej, Bydgoszcz-Warszawa, Wyższa Szkoła Gospodarki-Instytut Historii Nauki PAN 2011, 143-151.

5. Łbik L., Maciejewski J.: Trochę życia dla „Starej Drukarni”, „Express Bydgoski" 2006, nr 29, s. 12.

6. Majewski J.: Rozbudowa Starego Browaru w Poznaniu, „Architektura murator", 14, 9 (2007), 72-79.

7. Malkowski T.: Lofty $w$ dawnym spichlerzu $w$ Gliwicach, „Architektura murator", 17, 2 (2010), 60-66. 
8. Małachowicz E.: Konserwacja i rewaloryzacja architektury $w$ środowisku kulturowym, Wrocław, Oficyna Wydawnicza Politechniki Wrocławskiej 2007.

9. Markowski T., Kaczmarek S., Olenderek J.: Rewitalizacja terenów poprzemystowych $w$ Łodzi, Warszawa, Komitet Przestrzennego Zagospodarowania Kraju PAN 2010.

10. Renowacja obiektów dziedzictwa kulturowego na terenie Wyspy Młyńskiej w Bydgoszczy, redaktor I. Loose, Bydgoszcz, Urząd Miasta Bydgoszczy b.d.

11. Rewitalizacja kompleksu Księżego Młyna, redaktor T. Markowski, Warszawa, Komitet Przestrzennego Zagospodarowania Kraju PAN 2006.

12. Rouba B.: Dlaczego adaptacje niszczq zabytki i czy tak być musi?, w: Adaptacja obiektów zabytkowych do wspótczesnych funkcji użytkowych, redaktor B. Szmygin, Warszawa-Lublin, Lubelskie Towarzystwo Naukowe 2009, 113-129.

13. Stiasny G.: Lofty $w$ dawnej fabryce Scheiblera $w$ Łodzi, „Architektura murator", 17, 9 (2010), 60-69.

14. Szygendowski W., Walczak B.M.: Adaptacje zespołów zabytkowych we wspótczesnych realiach społeczno-gospodarczych na przykładzie dziedzictwa poprzemysłowego Łodzi, w: Adaptacja obiektów zabytkowych do wspótczesnych funkcji użytkowych, redaktor B. Szmygin, WarszawaLublin, Lubelskie Towarzystwo Naukowe 2009, 137-157.

\section{PROBLEMY ADAPTACJI DZIEDZICTWA POPRZEMYSEOWEGO NA PRZYKŁADZIE WYBRANYCH OBIEKTÓW BYDGOSKICH}

\section{Streszczenie}

Negatywne skutki przestrzenne, wynikające z procesów restrukturyzacji przemysłu, widoczne są w postaci nieużytków przemysłowych, zdegradowanych terenów i obiektów postindustrialnych. Do niedawna były one traktowane jako pozbawione wartości i znaczenia ze względu na zużycie technologiczne, świadomość ta jednak w ostatnich latach ulega wyraźnej zmianie. Coraz powszechniejsze staje się docenianie wartości kulturowych tej gałęzi architektury, w związku z tym podejmuje się zabiegi rewitalizacji i adaptacji zdegradowanych terenów poprzemysłowych. Charakterystyczne zagadnienia i problemy, związane $\mathrm{z}$ adaptacją tego typu obiektów, zostały omówione na podstawie wybranych przykładów adaptacji, zrealizowanych w ostatnich latach na terenie Bydgoszczy: XIX-wiecznego młyna (funkcja hotelowa), zespołu obiektów przemysłowych z XVIII-XIX wieku na Wyspie Młyńskiej (rewitalizacja na cele rekreacyjno-kulturalne) oraz strefy produkcyjnej nitrogliceryny z lat II wojny światowej, przeznaczonej na muzeum technik wojennych. Prezentacja tych obiektów i 
przeprowadzonych prac pozwoliła na sformułowanie istotnych uwag i wniosków odnośnie adaptacji tego typu obiektów.

Słowa kluczowe: dziedzictwo poprzemysłowe, adaptacja, rewitalizacja, Bydgoszcz

Editor received the manuscript: 18.11 .2015 
